\title{
Phytotonic Effect of Fungicide Mixtures Applied at Different Periods in Sweet Corn
}

\author{
Estevam M. Costa ${ }^{1}$, Matheus V. A. Ventura ${ }^{1}$, Bruno M. Nunes ${ }^{2}$, Roberto K. Mortate ${ }^{3}$, Mirian Nomura ${ }^{2}$, \\ Jaíza F. R. Chagas ${ }^{4}$, Bruno H. T. Arantes ${ }^{1}$, Marcio M. Bessa ${ }^{5}$, Victor H. Moraes ${ }^{1}$, Rafael M. da Silva ${ }^{6}$, \\ Alessandra P. A. Lima ${ }^{7} \&$ Marcia R. Oliveira ${ }^{8}$ \\ ${ }^{1}$ Postgraduate Program in Agrarian Sciences-Agronomy, Goiano Federal Institute, Rio Verde, Brazil \\ ${ }^{2}$ School of Agronomy, University of the State of Minas Gerais, Ituiutaba, Brazil \\ ${ }^{3}$ Postgraduate in Agronomy Sustainability in Agriculture, State University of Mato Grosso do Sul, Cassilandia, \\ Brazil \\ ${ }^{4}$ Postgraduate Program in Plant Production, Federal University of Tocantins, Gurupi, Brazil \\ ${ }^{5}$ Postgraduate Program in Geography, Paulista State University, Marilia, Brazil \\ ${ }^{6}$ Postgraduate Program in Irrigation in the Cerrado, Goiano Federal Institute, Ceres, Brazil \\ ${ }^{7}$ School of Agronomy, Evangelical Faculty of Goianesia, Goianesia, Brazil \\ ${ }^{8}$ School of Environmental Engineering, Federal University of Tocantins, Gurupi, Brazil \\ Correspondence: Estevam Matheus Costa, Postgraduate Program in Agrarian Sciences-Agronomy, Goiano \\ Federal Institute, Rio Verde, Brazil. Tel: 55-64-98406-8548. E-mail: estevammcosta@yahoo.com.br
}

Received: July 23, $2018 \quad$ Accepted: September 12, $2018 \quad$ Online Published: November 15, 2018

doi:10.5539/jas.v10n12p139 URL: https://doi.org/10.5539/jas.v10n12p139

\begin{abstract}
The fungicides belonging to the chemical groups of strobilurins and triazoles have their contribution to increase the productivity of the crop by a phytotoxic effect. The objective of this study was to evaluate the effects of fungicides at different times on the quality and quality of the spikes. The experiment was conducted at the Universidade do Estado de Minas Gerais and the experimental design was in randomized blocks, with 4 replicates, factorial factorial $3 \times 3+1$, the first factor being composed of 3 combinations of fungicides and the 2 applications (49, 56 and 63 days after sowing-DAS) +1 witness. The lot was composed of 4 rows spaced $0.45 \mathrm{~m}$ and the harvest was done manually at 83 DAS. The height of the plant, the height and the diameter of the glue in the first ear, total mass of ears with and without straw, grain mass per ear, length and diameter of the ears and productivity were evaluated. The data were analyzed by variance and as means compared by the Tukey test. The height of a plant was significantly affected throughout its life in the treatments at 63 days. The series were concentrated by the treatments are a non-spike mass, grain mass per spike and productivity, and pressure levels were loaded when they were performed at 63 DAS.
\end{abstract}

Keywords: ear quality, physiological effect, Zea mays

\section{Introduction}

Sweet corn (Zea mays subsp. saccharata) is a species of olive oil that has high added value and short cycle, since it is harvested green and is destined for human consumption, in natura or after industrial processing, due to its remarkable organoleptic characteristics like flavor sweetness of its grains. Sweet corn is unlikely to have occurred in the wild as a wild breed similar to other types of maize. It can be considered as a product of mutation, followed by domestication, as a new source of sugar would probably not be ignored by the indigenous tribes of various regions of South America, who would use sweet corn as a source of sugar (Parentoni et al., 1990).

The sweet character of the corn is due to the presence of mutant genes such as sugary, brittle and shrunken, which in homozygousness lead to a change in plant metabolism, resulting in the blockade of the conversion of sugars into starch in the endosperm (EMBRAPA, 1992). The difference between sweet corn and common corn is in the sugar and starch content of the endosperm. Thus, while common corn has around $3 \%$ sugar and between 60 and $70 \%$ starch, sweet corn has 9 to $14 \%$ sugar and 30 to $35 \%$ starch and the superdoce has around $25 \%$ sugar and 15 to $25 \%$ starch (Luz et al., 2014). 
The introduction of hybrids, increased use of fertilizers and other factors encourages the increase of plant densities. Along with this, the reduction of spacing that has been practiced tends to increase the incidence of diseases in the crop, be they foliar, thatch or spike. The corn crop is severely attacked by foliar diseases, making the use of fungicides fundamental in high yield crops. The application of this technology has demonstrated good gains in productivity and among the various chemical groups, the most commonly used is strobilurins and triazoles. The application and translocation of phytosanitary products may result in effects on plant metabolism, which depend on the species, dosage, physiological stage of the plant, environmental conditions, stress level of the plants and the molecules used in the application. It has been verified that for some crops, certain molecules mainly of the chemical group of strobilurins have demonstrated increase of productivity not only by the control of the incident diseases, but also by secondary effects in the physiology of cultivated plants or "physiological effect", which has been attributed the increase of liquid photosynthesis and the activity of the enzyme nitrate-reductase, combined with the decrease in the production of ethylene (Brachtvogel et al., 2010).

According Moura (2013), strobilurins have a conventionally called "green effect" effect on treated plants and this is due to a marked increase in the green area of crops in advanced stages of the cycle where chlorotic and necrotic areas normally predominate. According to this author, the application of triazoles is related to the reduction of height and stem diameter with consequent compaction of the crown and greater tolerance to drought due to the reduction in the rate of transpiration and increase in the production of cuticular wax. Another positive aspect observed in plants treated with triazoles is the better use of water due to changes in transpiration to fit in the stomata, associated with the increase in potassium concentrations in guards cells. The molecules of the strobilurin group act preventively inhibiting the germination of spores, presenting some curative and eradicating action, inhibiting the development of the fungi in the initial stages of post-germination, with antisporulating activity. The molecules are absorbed by the leaves in a gradual and constant manner, giving a protection on the surface for a longer time and diffusing through the leaf, presenting a uniform systemic distribution. With increasing humidity (mainly dew, spray and rain), surface redistribution and absorption of molecules are increased. The molecules in this group also exhibit translaminar diffusion. They are efficient against a large number of phytopathogens, covering all classes of fungi, at low concentrations, allowing a longer interval between applications (Venâncio et al., 1999; apud Rodrigues, 2009).

According Forcelini et al. (2002) apud Rodrigues (2009), the triazoles are organic fungicides and are mostly systemic, except for the fungicide bitertanol, classified as locossistêmico. They are absorbed and translocated by the plant acropetally and can act in a protective or curative way. They show high fungitoxicity, rapid penetration and translocation in the tissues of the plants, besides high residual effect. As protectors, these fungicides present a toxic action on spore germination; however, this protection is only partial, and pathogens may penetrate into treated tissues. In curative action, the development of haustrio and/or mycelial growth within the tissues is inhibited by the fungicide. Considering the socioeconomic importance of sweetcorn used for human consumption and the need for efficient protection of the crop against aggressive agents that compromise the productivity and quality of grains and ears, it becomes extremely important to know the most efficient protective products, as well as the best times of application. It is also necessary to carry out evaluations of which season or physiological stage the plant is during the application of fungicides and whether these times of application reflect on physiological changes and yield of spikes.

The objective of this study was to evaluate the physiological effects on plant phenology, spike characteristics and productivity, as a function of the application of different mixtures of fungicides belonging to the chemical groups of strobilurins and triazoles in different periods of application in sweet corn.

\section{Method}

The experiment was conducted at the Experimental Farm of the State University of Minas Gerais-Ituiutaba Unit, located in the municipality of Ituiutaba-MG (latitude $18^{\circ} 57^{\prime} 05.90^{\prime \prime} \mathrm{S}$, longitude $49^{\circ} 31^{\prime} 38.31^{\prime \prime} \mathrm{W}$ and $585 \mathrm{~m}$ altitude) between July and December 2015. The climate according to Koppen's classification is Aw type, tropical rainy, with an annual average temperature of $24{ }^{\circ} \mathrm{C}$ and an average annual rainfall of $1.470 \mathrm{~mm}$ and the soil classified as purple latosol. The experimental design was a randomized complete block design (DBC) based on a $3 \times 3+1$ factorial scheme, with four replications, the first factor being composed of three application times and the second factor composed of three combinations of fungicides $\left(\right.$ Nativo ${ }^{\circledR}$, Priori $X \operatorname{tra}{ }^{\circledR}$ and Opera ${ }^{\circledR}$, all belonging to the chemical groups of Strobilurins + Triazoles) +1 control (no application of any product at any time of application). The plots were composed of four $5.0 \mathrm{~m}$ long rows, spaced at $0.45 \mathrm{~cm}$, totaling $9.0 \mathrm{~m}^{2}$, and the two central rows were considered as useful area. The total area of the experiment was approximately $512 \mathrm{~m}^{2}$. 
Irrigation management was done through a fixed conventional sprinkler irrigation system, so that the soil was maintained with approximately $70 \%$ of the field capacity, considering daily evapotranspiration of $4 \mathrm{~mm}$. Soil sampling was performed at a depth of 0 to $0.20 \mathrm{~m}$ from the entire experimental area. The soil sample was sent to the soil analysis laboratory of the University of the State of Minas Gerais - Ituiutaba Unit. The report presented the following results (Table 1).

Table 1. Chemical soil analysis information in the experimental area

\begin{tabular}{|c|c|c|c|c|c|c|c|c|c|c|c|c|}
\hline $\mathrm{pH}$ & $\mathrm{P}$ & $\mathrm{K}$ & $\mathrm{Al}$ & $\mathrm{H}+\mathrm{Al}$ & $\mathrm{Ca}$ & $\mathrm{Mg}$ & $\mathrm{Sb}$ & $\mathrm{t}$ & $\mathrm{T}$ & M.O. & $\mathrm{m}$ & V \\
\hline water & \multicolumn{2}{|c|}{---- mg/dm ${ }^{3}----$} & ----- & - & ----- & $\mathrm{ol}_{\mathrm{c}} / \mathrm{dn}$ & ---- & --- & ------- & $\mathrm{g} / \mathrm{kg}$ & \multicolumn{2}{|c|}{------ \% ------ } \\
\hline 5.9 & 7.6 & 160.4 & 0.04 & 5.21 & 3.88 & 0.96 & 5.2 & 5.3 & 10.5 & 27 & 1.0 & 50.0 \\
\hline
\end{tabular}

The liming was performed 60 days before sowing according to the recommendations for the cultivation of the green corn, seeking to increase the saturation content by $60 \%$, with application of $1.20 \mathrm{t} \mathrm{ha}^{-1}$ as recommended by Ribeiro et al. (1999). After liming, a subsoiling operation was carried out, at a working depth of $0.40 \mathrm{~m}$, a plow with disc plows and a harrow with harrow. Seven harrows were harvested seven days before sowing, with leveling grid.

Seeding was carried out on September 20, 2016, using a manual seeder, regulated to deposit 5 seeds per linear meter of sowing furrow. The seed used was from the cultivar GSS 41243. At the time of sowing, no fertilization was carried out, due to the fact that the sowing model used did not have the fertilizer function, and this fertilization was performed twenty days after sowing with the application of $417 \mathrm{~kg}$ of formulation 04-14-08 per hectare (ha), distributed next to the plants in the initial phase of growth. Coating fertilizations were carried out in two phases, at 31 and 45 days after sowing, each containing $150 \mathrm{~kg}$ of urea per hectare, totaling $300 \mathrm{~kg} \mathrm{ha}^{-1}(132$ $\mathrm{kg} \mathrm{ha}^{-1}$ ), according to recommendations of Ribeiro et al. (1999). At the time of fertilization, the plants were thinned in order to maintain 2.70 plants per linear meter.

Weed control was performed with manual weeding at 22 days after sowing, while pest control was performed with two applications, at 23 and 51 days after planting, of systemic insecticide and Lannate ${ }^{\circledR}$ contact. The control of diseases was not carried out directly, as there was no attack of any pathogens, and according to the proposed objective, there would be the application of fungicides to investigate their potential physiological effects on the sweet corn crop. However, this control was performed indirectly during the choice of the area, since this is a new area, which had been cultivated only once with sweet corn, and therefore, there was not enough inoculum of pathogens to cause diseases in the plants. The treatments were described in Table 2.

Table 2. Description of the treatments used in the experiment, showing the mixtures made and the time of application of the treatments

\begin{tabular}{|c|c|c|}
\hline Treatment & Mixture & Application Time (days after sowing) \\
\hline Т 0 & Witness & Witness \\
\hline Т 1 & Priori Xtra ${ }^{\circledR}+$ Nativo $^{\circledR}$ & 49 \\
\hline Т 2 & Opera $^{\circledR}+$ Nativo $^{\circledR}$ & 49 \\
\hline Т 3 & Priori Xtra ${ }^{\circledR}+$ Opera $^{\circledR}$ & 49 \\
\hline $\mathrm{T} 4$ & Priori Xtra ${ }^{\circledR}+$ Nativo $^{\circledR}$ & 56 \\
\hline T 5 & Opera $\left.^{(}\right)+$Nativo $^{(}$ & 56 \\
\hline Т 6 & Priori Xtra ${ }^{\circledR}+$ Opera $\left.^{(}\right)$ & 56 \\
\hline Т 7 & Priori Xtra ${ }^{\circledR}+$ Nativo $^{\circledR}$ & 63 \\
\hline Т 8 & Opera $^{\circledR}+$ Nativo $^{\circledR}$ & 63 \\
\hline Т 9 & Priori Xtra ${ }^{\circledR}+$ Opera $\left.^{(}\right)$ & 63 \\
\hline
\end{tabular}

The time of application of the treatments was performed according to Table 2, following the recommendations provided by the manufacturers and contained in the respective package inserts. The mixtures and syrups were prepared just prior to application according to the recommended syrup volume and commercial dosage per hectare (L p.c. ha ${ }^{-1}$ ). Soon after the preparation of the syrup, it was placed in a $10 \mathrm{~L}$ costal pump and spraying was performed. 
The evaluation of the morphological characteristics of the plants and the harvest was carried out 83 days after sowing, in the morning, four ears of the useful area of each plot were collected at random. During the harvest, the characteristics of the plants that had their ears harvested were evaluated and the ears were packed in plastic bags with their proper identifications and then taken to the Laboratory of Sugar and Alcohol Technology of the State University of Minas Gerais-Ituiutaba Unit for the due evaluations. The following characters were evaluated from the plants within the useful area of each plot that had their ears harvested:

a) Total height of the plants: The measurement was carried out with the aid of a measuring tape, measuring from the lap to the insertion of the flag leaf at 83 days after sowing before harvesting;

b) Height and stem diameter at first ear insertion: Measurement was performed with a tape measure to measure the height of the colon until insertion of the first viable ear and a pachymeter to measure the diameter at 83 days after sowing before the harvest;

c) Total weight of ears with straw and without straw: The ears were weighed first with straw and after weeding, they were weighed again;

d) Weight of grains per spike: After threshing, the grains of each spike were weighed to determine the weight of grains per spike;

e) Length and diameter of the spikes: A trena was used to obtain the length of the spike, while for the diameter a pachymeter was used. These measurements were taken after the removal of the straw.

f) Productivity: Productivity was calculated using the following formula (according to Equation 1):

$$
\text { Productivity }(\mathrm{t} / \mathrm{ha})=\frac{\text { Weight of grains per ear }(\mathrm{g}) \times \text { population }}{1000000}
$$

Where, Grain weight per spike $=$ total weight of grains of a spike; Population $=$ Final population of plants; $1000000=$ conversion factor (converting from grams to tons).

The data were submitted to Variance Analysis by the F test and the means were compared by the Tukey test at $5 \%$.

\section{Results}

Table 3. Analysis of variance (ANOVA) and Tukey's test for the characteristics of plants evaluated in loco

\begin{tabular}{lllllll}
\hline \multirow{2}{*}{ Source of Variation } & \multicolumn{7}{c}{ F } \\
\cline { 2 - 7 } & \multicolumn{1}{l}{ Plant Height $(\mathbf{c m})$} & First ear insertion height (cm) & Diameter at first ear insertion (cm) \\
\hline Factor 1 (Season) & 3.85 & $*$ & 1.58 & $\mathrm{~ns}$ & 1.24 & $\mathrm{~ns}$ \\
Factor 2 (Mixture) & 0.74 & $\mathrm{~ns}$ & 0.05 & $\mathrm{~ns}$ & 0.04 & $\mathrm{~ns}$ \\
Int. F1 $\times$ F2 & 0.90 & $\mathrm{~ns}$ & 0.65 & $\mathrm{~ns}$ & 1.12 & $\mathrm{~ns}$ \\
Factorial $\times$ Witness & 0.59 & $\mathrm{~ns}$ & 0.32 & $\mathrm{~ns}$ & 0.96 & $\mathrm{~ns}$ \\
\hline Treatments & 1.48 & $\mathrm{~ns}$ & 0.69 & $\mathrm{~ns}$ & $0.89 \mathrm{~ns}$ \\
\hline DMS (F1 e F2) & 12.79 & & 10.54 & 0.11 & \\
DMS (F1× F2) & 22.16 & 18.25 & 0.19 & \\
CV (\%) & 7.26 & 10.80 & 6.52 \\
Average Overall & 175.53 & 97.11 & 1.71 \\
\hline
\end{tabular}

Note. *: significant at the $5 \%$ probability level. ns: not significant. 
Table 4. Analysis of variance (ANOVA) and Tukey's test for spike characteristics, yield and productivity

\begin{tabular}{|c|c|c|c|c|c|c|c|c|c|c|c|c|}
\hline \multirow{3}{*}{$\begin{array}{l}\text { Source of Variation } \\
\text { Factor } 1 \text { (Season) }\end{array}$} & \multicolumn{12}{|c|}{$\mathbf{F}$} \\
\hline & \multicolumn{2}{|c|}{$\begin{array}{l}\text { Ear length } \\
\text { (cm) }\end{array}$} & \multicolumn{2}{|c|}{$\begin{array}{l}\text { Diameter } \\
\text { of ear }(\mathbf{c m})\end{array}$} & \multicolumn{2}{|c|}{$\begin{array}{l}\text { Pasta with ears } \\
\text { of corn (g) }\end{array}$} & \multicolumn{2}{|c|}{$\begin{array}{l}\text { Pasta without } \\
\text { ears (g) }\end{array}$} & \multicolumn{2}{|c|}{$\begin{array}{l}\text { Weight of grains } \\
\text { per ear }(g)\end{array}$} & \multicolumn{2}{|c|}{$\begin{array}{l}\text { Productivity } \\
\text { (t/ha) }\end{array}$} \\
\hline & 2.71 & ns & 0.28 & ns & 3.13 & $\mathrm{~ns}$ & 5.43 & $* *$ & 10.93 & $* *$ & 10.93 & $* *$ \\
\hline Factor 2 (Mixture) & 0.39 & ns & 0.62 & ns & 1.37 & ns & 1.79 & ns & 2.19 & ns & 2.19 & $\mathrm{~ns}$ \\
\hline Int. F1 × F2 & 0.34 & ns & 1.71 & ns & 3.59 & $*$ & 3.38 & $*$ & 1.88 & ns & 1.88 & ns \\
\hline Factorial $\times$ Witness & 0.87 & $\mathrm{~ns}$ & 0.51 & $\mathrm{~ns}$ & 0.60 & $\mathrm{~ns}$ & 1.39 & $\mathrm{~ns}$ & 1.00 & ns & 1.00 & $\mathrm{~ns}$ \\
\hline Treatments & 0.94 & ns & 1.01 & ns & 2.66 & $*$ & 3.26 & $* *$ & 3.86 & $* *$ & 3.86 & $* *$ \\
\hline DMS (F1 e F2) & 1.62 & & 0.35 & & 41.07 & & 32.49 & & 13.84 & & 0.83 & \\
\hline DMS (F1×F2) & 2.81 & & 0.61 & & 71.14 & & 56.27 & & 23.98 & & 1.44 & \\
\hline CV (\%) & 8.69 & & 7.01 & & 12.47 & & 12.66 & & 11.07 & & 11.07 & \\
\hline Average Overall & 18.59 & & 4.98 & & 327.92 & & 255.38 & & 124.54 & & 7.47 & \\
\hline
\end{tabular}

Note. ${ }^{* *}$ : significant at the $1 \%$ probability level. $*$ : significant at the $5 \%$ probability level. ns: not significant.

Table 5. Averages of factor 1 (application time) referring to the total height of the plants

\begin{tabular}{ll}
\hline Treatment & Total Plant Height \\
\hline $49 \mathrm{DAS}^{1}$ & $176.77 \mathrm{ab}$ \\
$56 \mathrm{DAS}^{1}$ & $168.50 \mathrm{~b}$ \\
$63 \mathrm{DAS}^{1}$ & $182.88 \mathrm{a}$ \\
Average & 176.05 \\
Witness & 170.88 \\
F & $3.8506^{*}$ \\
DMS & 12.79 \\
CV $(\%)$ & 7.26
\end{tabular}

Note. ${ }^{1}$ Days After Sowing. The averages followed by the same letter do not differ statistically from each other. The Tukey test was applied at a $5 \%$ probability level.

Table 6. Averages of factor 1 (application time) referring to the components that determine productivity (ear mass, grain weight per ear and productivity)

\begin{tabular}{|c|c|c|c|}
\hline Treatment & Weight of spikes without straw & Weight of Grains per Spike & Productivity \\
\hline $49 \mathrm{DAS}^{1}$ & $248.91 \mathrm{~b}$ & $121.71 \quad \mathrm{~b}$ & $7.30 \quad \mathrm{~b}$ \\
\hline $56 \mathrm{DAS}^{1}$ & $241.15 \mathrm{~b}$ & 114.26 & 6.86 \\
\hline $63 \mathrm{DAS}^{1}$ & $282.09 \mathrm{a}$ & 139.83 & 8.39 \\
\hline Average & 257.38 & 125.27 & 7.52 \\
\hline Witness & 237.31 & 118.00 & 7.08 \\
\hline $\mathrm{F}$ & $5.43^{* *}$ & $10.93^{* *}$ & $10.93 * *$ \\
\hline DMS & 32.49 & 13.84 & 0.83 \\
\hline $\mathrm{CV}(\%)$ & 12.66 & 11,07 & 11.07 \\
\hline
\end{tabular}

Note. ${ }^{1}$ Days After Sowing. The averages followed by the same letter do not differ statistically from each other. The Tukey test was applied at the $1 \%$ probability level. 
Table 7. Averages of interaction F1 $\times$ F2 for the characteristic of weight of ears with straw

\begin{tabular}{|c|c|c|c|c|}
\hline \multirow{2}{*}{ Time } & \multicolumn{4}{|c|}{ Mixture of fungicides } \\
\hline & 1 & 2 & 3 & Average \\
\hline 1 & $320.90 \quad \mathrm{aA}$ & $299.44 \quad \mathrm{aA}$ & $333.13 \mathrm{abA}$ & 317.82 \\
\hline 2 & $324.94 \mathrm{aA}$ & 338.69 aA & $269.06 \mathrm{bA}$ & 310.90 \\
\hline 3 & $374.56 \mathrm{aA}$ & $299.39 \mathrm{aB}$ & $376.19 \mathrm{aA}$ & 350.05 \\
\hline Average & 340.13 & 312.50 & 326.13 & 327.92 \\
\hline Witness & 342.88 & & & \\
\hline $\mathrm{F}$ & 3.59 & & & \\
\hline DMS & 71.14 & & & \\
\hline CV (\%) & 12.47 & & & \\
\hline
\end{tabular}

Note. Averages with lowercase letters do not differ from each other in the same column. Averages with capital letters do not differ from each other on the same line. The Tukey test was applied at a 5\% probability level.

Table 8. Means of Interaction F1 $\times$ F2 for the mass characteristic of spikes without straw

\begin{tabular}{|c|c|c|c|c|c|c|c|}
\hline \multirow{2}{*}{ Time } & \multicolumn{7}{|c|}{ Mixture of fungicides } \\
\hline & 1 & & 2 & & 3 & & Average \\
\hline 1 & 243.63 & $\mathrm{bA}$ & 239.18 & $\mathrm{aA}$ & 263.94 & $\mathrm{abA}$ & 248.91 \\
\hline 2 & 260.56 & $a b A$ & 253.63 & $\mathrm{aA}$ & 209.25 & $\mathrm{bA}$ & 241.15 \\
\hline 3 & 304.14 & $\mathrm{aA}$ & 240.76 & $\mathrm{aB}$ & 301.38 & $\mathrm{aA}$ & 282.09 \\
\hline Average & 269.44 & & 244.52 & & 258.19 & & 255.38 \\
\hline Witness & 237.31 & & & & & & \\
\hline $\mathrm{F}$ & 3.38 & & & & & & \\
\hline DMS & 56.27 & & & & & & \\
\hline CV $(\%)$ & 12.66 & & & & & & \\
\hline
\end{tabular}

Note. Averages with lowercase letters do not differ from each other in the same column. Averages with capital letters do not differ from each other on the same line. The Tukey test was applied at a 5\% probability level.

\section{Discussion}

Table 3 shows the variance analysis and Tukey's test (0.05) for the phenological characteristics of the plants (total plant height, first ear insertion height and stem diameter at the first ear insertion).

As observed in Table 3, the only characteristic affected was the height of the plants that received fungicide application at 49 days after sowing (application time 1). Despite this, we can observe that according to Ribeiro et al. (2014), in his work on soybean cultivation, stated that the use of fungicides in the flowering of soybeans (R1 and R2) showed increases in plant height compared to their control treatment. Moreover, in the bean crop, Kozlowski et al. (2009) also observed that the use of pyraclostrobin influenced plant height.

According to Silva (2017), there was no significant difference between treatments for plant height and height of first ear insertion using fungicides composed of triazole, strobilurin, dithiocarbamate and carboxamide.

Table 4 shows the analysis of variance and the Tukey's test (0.05) for the trait characteristics (length, diameter, spike mass with and without straw) and grain weight per spike and productivity, that there was a statistically significant difference when analyzed the factor 1 corresponding to the different times of application, spike mass without straw, grain weight per spike and productivity. In addition to these characteristics, a statistically significant difference was observed for the characteristics of spike mass with straw and unleaved ear mass in the interaction between factor 1 (application time) and factor 2 (different mixtures).

According to Table 4, it can be observed that the time of application affected the mass production of the no-tang ears and the total productivity. There was interaction between the mixtures and the times on the mass production of the ears with straw and without straw. The other characteristics were not affected.

There was no statistical difference in relation to the fungicide mixtures (factor 2). In the case of Silva (2017), the highest productivities were achieved in the treatments with the chemical group of fungicides of the carboxamides, that is, the mixtures were (triazol + strobilurin $)+($ strobilurin + carboxamide $) ;[$ (triazole + strobilurin $)+$ 
dithiocarbamate + (strobilurin + carboxamide) $]$ and (strobilurin + carboxamide). These results are due to the greater efficiency of the treatments in the repair of the photosynthetic apparatus for the production of photoassimilates, consequently, maintenance of the leaf area.

It is observed that the application of the fungicides to 63 DAS (Days After Sowing) resulted in an increase in the height of the plants when compared to the other seasons. This effect can be explained by the fact that the triazoles contribute to the reduction of plant height and, because they have been applied at a later stage of the crop cycle, and with this, the plants are already in a more advanced state of vegetative development. In contrast, the application of the fungicides at 56 days may have reflected in order to decrease the height of these plants, evidencing the effect that the triazoles can cause to reduce the height of the plants. According to Moura (2013), the application of triazoles is related to the reduction of the height and diameter of the stem of the treated plants.

In the work of Simnonetti and Figueira (2016), using the mixture of fungicides Strobilurin + Triazol observed significant values for plant height in relation to the combination of the + silicate (Strobilurin + Triazole) and the control.

Regarding the diameter, it was already expected that this would not be changed, since, this characteristic is defined in initial stages of the culture, period before the application of the fungicides. This result was also found by Simnonetti and Figueira (2016).

The application of the fungicide mixtures to the 63 DAS resulted in an increase in the mass of the ears without straw, in the weight of grains per spike and, consequently, in the productivity, when compared to the other seasons. The cause of the increase in the production of spikes and grains, and consequently in the productivity, may have been due to the fact that the plants have a higher concentration of strobilurins in their cells and this may have led to the increase of productivity due to the fact that these substances reduce senescence and increase the chlorophyll content in the leaves at the end of the crop cycle (Habermeyer et al., 1998; Rodrigues, 2009).

For the other application times, at 49 and 56 DAS, where the productivity was lower than that obtained in the application performed at 63 DAS, what may have occurred is that the concentration of strobilurins in the plant cells was lower, and with that the effects provided for these in the plants, such as reduction of senescence and increase of chlorophyll content, was lower in the grain filling stage (Rodrigues, 2009).

For the other evaluated characteristics, height and diameter at the first ear insertion; length of spike and mass of spikes with straw, there was no statistically significant difference in the times of application of fungicides.

Regarding factor 2 (mixture between fungicides), no difference was found for any of the nine characteristics evaluated. Thus, none of the mixtures between the fungicides expressed statistically superior or inferior results to the other mixtures between the fungicides used.

When analyzing the interaction factor $1 \times$ factor 2 , it was verified that there was difference in the characteristics of the weight of ears with straw and weight of ears without straw, as shown in Tables 7 and 8.

Observing Table 7, it is noted that, regardless of the application time, there was no effect of mixtures 1 and 2 on the mass of the ears with straw. The application of blend 3, at 63 DAS, provided a higher weight of spikes with straw when compared to application at DAS. In the application to the 63 DAS, the blend 2 provided a lower yield of the weight of ears with straw when compared to the other mixtures. When analyzing only the columns, it was observed that the application of the mixture 3 (Priori Xtra ${ }^{\circledR}+$ Nativo ${ }^{\circledR}$ ), in season 2 (56 Days After Emergency - DAE), differed statistically from the other treatments, and its result (weight of ears with straw) to the other results obtained, whereas the mixture 3 applied in season 1 (49 DAE) was statistically equal to all treatments applied. For the other treatments there are no statistically significant differences between them.

According to Table 8, it can be seen that, at 63 DAS, blend 1 provided a higher weight of ears without straw compared to the application performed at 49 DAS. For mixture 2, the application time did not affect the weight of the ears without straw. The application of blend 3, at 63 DAS, provided a larger mass of ears without straw when compared to the applied application at 59 DAS. The mixtures 1 and 3 to 63 DAS, provided greater weight of corn straw without mixing 2 . With respect to evaluation of mixture 1 (+ Nativo ${ }^{\circledR}$ Priori Xtra) when applied at the time 3 (63 DAS), the weight without straw of corn was higher than the treatment which received this same mixture of fungicides in one season (49 DAS), while treatment it received at the time this mixture 2 (56 DAS) was statistically similar to the first two treatments.

Because the application at the time 3 has been performed in a do when the plants were more at the end of its cycle, it can contribute more efficiently to increase productivity than those treatments receiving the application after 49 days sowing (season 1 ). 
For the treatments that received the blend $2\left(\right.$ Opera $\left({ }^{\circledR}+\right.$ Nativo $\left.{ }^{\circledR}\right)$, in any season, there is no statistical evidence that the means are different at the $5 \%$ probability level.

When the blend 3 (Priori $X \operatorname{tra}{ }^{\circledR}+$ Opera ${ }^{\circledR}$ ) was evaluated, it is again noted that when this fungicide blend was applied at 63 days after sowing, the mass results of the no-straw ears were higher. However, unlike the application of mixture 1, the application of mixture 3 in season 1 was statistically equal to the treatments that received the application in season 2 and season 3, while the mixture three in season two differed statistically from the others times, being its inferior result.

Regarding the time of application, the only treatment that differed statistically from the others was the one that received the application of the mixture 2 in the period 3 (63 DAS), being its result inferior to the other results at the level of $5 \%$ of probability $(0.01 \leq \mathrm{p}<0.05)$.

Regarding the analysis of the factorial treatments versus the control treatment (factorial $\times$ control), no statistically significant difference was observed at the $5 \%$ probability level $(0.01 \leq \mathrm{p}<0.05)$.

The application of the fungicides at 63 days after planting resulted in increased plant height, however, did not present significant influence on the other characteristics evaluated in the plant itself. This same application may have exerted a positive influence in increasing the weight of the spikes with straw, weight of the grain of the spikes and the productivity.

\section{References}

Barbieri, V. H. B. (2010). Mapeamento de QTL em testecrosses de milho doce com diferentes testadores e ambientes (Doctoral thesis, Escola Superior de Agricultura "Luiz de Queiroz").

Brachtvogel, E. L. (2010). População de plantas e uso de piraclostrobina na cultura do milho: Alterações agronômicas e fisiológicas (Doctoral thesis, Faculdade de Ciências Agronômicas da UNESP).

Brachtvogel, E. L., Pereira, F. R. D. S., Cruz, S. C. S., \& Bicudo, S. J. (2009). Maize plant densities in conventional and equidistant plant spacing. Ciência Rural, 39(8), 2334-2339. https://doi.org/10.1590/ S0103-84782009005000193

Costa, R. V. da, \& Cota, L. V. (2009). Controle químico de doenças na cultura do milho: Aspectos a serem considerados na tomada de decisão sobre aplicação. Embrapa Milho e Sorgo, Circular Técnica.

EMBRAPA (Embrapa Milho e Sorgo). (1992). A cultura do milho doce. Centro Nacional de Pesquisa de milho e Sorgo, Circular Técnica 18.

Fornasieri Filho, D. (1992). A cultura do milho. Jaboticabal: FUNEP.

Fornasieri Filho, D. (2007). Manual da cultura do milho. Jaboticabal: FUNEP.

Kozlowski, L. A., Simões, D. F. M., de Souza, C. D., \& Trento, M. (2009). Physiological effects os strobillurins F 500 in the growth and yield of bean. Revista Acadêmica: Ciência Animal, 7(1), 41-54. https://doi.org/ 10.7213/cienciaanimal.v7i1.8906

Kwiatkowski, A., \& Clemente, E. (2007). Características do milho doce (Zea mays L.) para industrialização. Revista Brasileira de Tecnologia Agroindustrial, 1(2), 93-103. https://doi.org/10.3895/S1981-3686200700 0200010

Luz, J. M., Camilo, J. S., Barbieri, V. H., Rangel, R. M., \& Oliveira, R. C. (2014). Productivity of sweet corn and green corn genotypes according to harvest intervals. Horticultura Brasileira, 32(2), 163-167. https://doi.org/10.1590/S0102-05362014000200007

Moura, P. C. S. (2013). Efeitos fisiológicos da aplicação de triazol e estrobilurina em soja (Masters dissertation, Escola Superior de Agricultura "Luiz de Queiroz").

Parentoni, S. N., Gama, E. E. G., Magnavaca, R., Reifschneider, F. J. B., \& Boas, G. L. V. (1990). Milho doce. Informe Agropecuário, 14(165), 17-22.

Paula Júnior, T. J., \& Venzon, M. (2007). 101 Culturas: Manual de tecnologias agrícolas. Belo Horizonte: EPAMIG.

Pedro Junior., M. J., Bulisani, E. A., Pommer, C. V., Passos, F. A., Godoy, I. J., \& Aranha, C. (1987). Instruções agrícolas para o Estado de São Paulo (IAC, Boletim 200). Campinas: IAC.

Pereira Filho, I. A. (2003). O cultivo do milho-verde. Embrapa Milho e Sorgo, Sete Lagoas, MG. 
Pinto, N. F. J. A., Angelis, B., \& Habe, M. H. (2004). Avaliação da eficiência de fungicidas no controle da cercosporiose (Cercospora zeae-maydis) na cultura do milho. Revista Brasileira de Milho e Sorgo, 3(1), 139-145. https://doi.org/10.18512/1980-6477/rbms.v3n1p139-145

Ribeiro, A. C., Guimaraes, P. T. G., \& Alvarez, V. H. (Ed.). (1999). Recomendação para o uso de corretivos e fertilizantes em Minas Gerais. Viçosa: Comissão de Fertilidade do Solo do Estado de Minas Gerais.

Ribeiro, W. R. M., Pacheco, L. P., Monteiro, F. P., Carvalho, W. L., Sousa, T., O., \& Gualberto, A. V. S. (2014). Fungicides phytotonic action on the development of soybean. African Journal of Agricultural Research, 9(44), 3283-3290.

Rodrigues, M. A. T. (2009). Avaliação do efeito fisiológico do uso de fungicidas na cultura de soja (Doctoral thesis, Escola Superior de Agricultura "Luiz de Queiroz").

Silva, F. A. S., \& Azevedo, C. A. V. (2009). Principal Components Analysis in the Software Assistat-Statistical Attendance. World Congress on Computers in Agriculture, 7, Reno-NV-USA: American Society of Agricultural and Biological Engineers.

Silva, M. F. (2017). Influência de fungicidas na integridade de colmo e produtividade na cultura do milho (Monography, Universidade Federal de Uberlândia).

Silva, O. C., \& Schipanski, C. A. (2006). Manual de identificação e manejo das doenças do milho. Castro: Editora Fundação ABC.

Silva, O. C., Schipanski, C. A., \& Veiga, J. (2007). Obstáculo à produção. Caderno técnico doenças circula encartado na revista Cultivar Grandes Culturas, 94, 3-10.

Simnonetti, A. P. M. M., \& Figueira, C. R. (2016). Aplicação do silicato de potássio e fungicida sobre pulgão, enfezamento vermelho e no desenvolvimento de plantas de milho. Revista Thêma et Scientia, 1(1), 163-171.

Taiz, L., \& Zeiger, E. (2004). Fisiologia Vegetal (3rd ed.). Porto Alegre: Artmed Editora.

Tofoli, J. G. (2002). Ação de fungicidas e acibenzolar-se-methyl no controle da pinta preta do tomateiro (Masters dissertation, Universidade Estadual Paulista, Faculdade de Ciências Agronômicas).

Zambolim, L., Picanço, M. C., Silva, A, A., Ferreira, F, A., \& Jesus Junior, W, C. (2008). Produtos Fitossanitários — Fungicidas, Inseticidas, Acaricidas e Herbicidas. Viçosa: Editoria UFV.

\section{Copyrights}

Copyright for this article is retained by the author(s), with first publication rights granted to the journal.

This is an open-access article distributed under the terms and conditions of the Creative Commons Attribution license (http://creativecommons.org/licenses/by/4.0/). 